\title{
PRODUCTION OF PROTEIN CONCENTRATE AND ISOLATE FROM \\ CASHEW (Anacardium occidentale L.) NUT
}

Ogunwolu $\mathrm{SO}^{1,2,3}$, Henshaw $\mathrm{FO}^{2}, \mathrm{Mock} \mathrm{HP}^{3}$ and $\mathrm{A} \mathrm{M}$ atros ${ }^{3}$

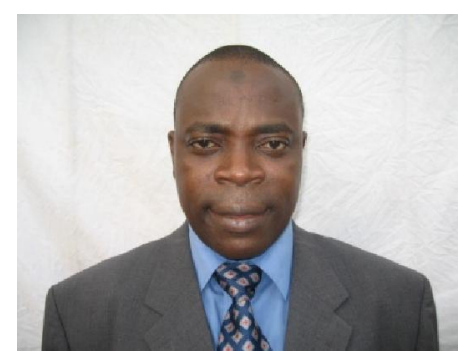

Semiu Ogunwolu

* Corresponding author email: olalekansemiu@ yahoo.com

${ }^{1}$ Crop Processing and Utilization Division, Cocoa Research Institute of Nigeria, P.M.B. 5244, Ibadan Nigeria.

${ }^{2}$ Department of Food Science and Technology, University of Agriculture, P.M.B. 2240, Abeokuta, Nigeria.

${ }^{3}$ Applied Biochemistry group, Leibniz Institute of Plant Genetics and Crop plant Research, Corrensstraße 3, D-06466 Gatersleben, Germany. 


\section{ABSTRACT}

The study evaluated methods of producing protein concentrates and isolates from cashew nut in order to increase the global utilization of cashew nut and increase the availability of affordable, good quality protein for people. Cashew nuts were processed to obtain roasted cashew kernel. The roasted cashew kernels were processed into powder by cold solvent extraction of the fat in the cashew meal. Proximate composition of the cashew nut and meal were determined to ascertain the protein content of the cashew nut. The extraction of the proteins was done using two different methods based on the known methods of production of protein isolate and concentrate from other plant sources (peanut), since there are no familiar methods for the production of protein isolate and concentrate from cashew nut. The protein isolates were obtained by an alkaline extraction-isoelectric precipitation method, which involved aqueous alkaline extraction of the proteins at low temperature, and isoelectric precipitation of the protein fractions; the protein concentrates were obtained using an alkaline extraction-methanol precipitation method, which involved aqueous alkaline extraction of the proteins at low temperature, and alcoholic precipitation of the protein fractions. Extraction ratios of 1:5 and 1:10, extraction $\mathrm{pH}$ of 7.0 and 9.0, and isoelectric precipitation at $\mathrm{pH}$ of 3.5 and 4.5 were used to obtain eight cashew protein fractions of different protein contents (44.4 to 99.8\%) and different protein yields (48.3 to $98.9 \%$ ) from the use of the isoelectric precipitation methods. Similarly, using the methanol precipitation method, extraction ratio of 1:5 and 1:10, pH of 7.0 and 9.0, and concentrations of methanol of $70 \%$ and $80 \%$, were used to obtain eight cashew protein fractions of varying protein contents (64 to 89\%), and protein yields (52.1 to 88.2\%). Protein contents of the cashew protein fractions were determined using 2-D Quant kit method, while the protein yields were calculated using the weight of the protein fractions obtained from the cashew meal of known weight. From the results of the protein content analysis of the protein fractions and according to the CODEX Standard, it was demonstrated that, cashew nut protein isolate (99.8\% protein content), and, cashew nut protein concentrate of varying protein contents could be obtained from the isoelectric precipitation method, while only protein concentrate was obtained using the methanol precipitation method.

K ey words: Cashew Nut, Protein, Isolate, Concentrate 


\section{INTRODUCTION}

Cashew (Anacardium occidentale L.) belongs to the family Anacardiaceae, with about 75 genera and 700 species. Cashew is a tropical tree species cultivated in many tropical countries of the world from its centre of origin in South and Central America to Africa, Asia and tropical Australia [1].

Cashew fruit is made up of the apple that bears the fruit in which the kernel is embedded. The nut is composed of the kernel and shell. The shell is about $3 \mathrm{~mm}$ thick and comprises roughly $45-50 \%$ of the total weight of the nut [2]. The kernel is slightly curved back on itself and is formed of two cotyledons, representing about 20-25\% of the nut weight; it is wrapped in a thin, resistant peel (testa) like a membrane, with a reddish-brown colour, which in turn approximates to $5 \%$ of the whole nut.

Cashew kernel is of high food value with about $40-57 \%$ oil, and $21 \%$ protein [3]. It is an important delicacy that is mainly used in confectionery and as a dessert nut. The kernel can be roasted and consumed; it can also be used as an adjunct in chocolate and chicken feeds [4]. The powdered milk used in standard milk chocolate recipe can be replaced with $25 \%$ roasted cashew kernel [5].

Proteins utilized in food processing are of various origins, and can be roughly grouped into animal proteins (gelatine), vegetable proteins (e.g. Soya protein), and animalderived protein (milk proteins) [6]. According to Moure et a.I [7], proteins that are essential to growth and health are currently required more in the developing countries of the world, because of the chronic problem of protein-energy malnutrition. Shortages and high prices have recently caused restriction of animal proteins in the diets of many families in the developing countries of the world. However, vegetable proteins which are cheaper and available are of great potentials as a direct food for human consumption. Many of the vegetable proteins require processing to provide a food material that has acceptable organoleptic properties for human consumption [8]. According to McWatters and Cherry [9], protein components of plants are regarded as important source of ingredients in food systems, because of their unique functional properties, such as emulsification, fat and water absorption, texture modification, colour control and whipping properties.

In view of increasing production of cashew globally, there is need for increased utilization of cashew nut, especially the nutritious cashew kernel. Cashew kernels are therefore being considered as an additional source of protein concentrate and isolate for use in human food products.

The objectives of this work, therefore, are to determine the appropriate production methods for the production of protein concentrates and isolates from cashew nut and to determine the protein content and protein yield of the concentrates and isolates. 


\section{MATERIALSAND METHODS}

\section{Source of materials}

Cashew nuts were obtained from the cashew plots of the Cocoa Research Institute of Nigeria, Ibadan, Nigeria. Chemicals and equipments used were obtained from the Applied Biochemistry Group of the Institute for Plant Genetics and Crop Plant Research, Gatersleben, Germany.

\section{Cashew nut processing}

The processing of cashew nuts was done by the method of Falade et al [10]; a batch of dried wholesome cashew nuts was steamed in a retort at $121^{\circ} \mathrm{C}$ and $5 \mathrm{lb}$ pressure for $5 \mathrm{~min}$ and then allowed to cool. The cashew nuts were manually cut into two equal halves using a hand-operated cashew nut sheller. The kernels were then separated from the shells using small knives. The kernels were air-dried in a cabinet (BR185H, Gallenkamp, Yorkshire, UK) oven at a temperature of $50^{\circ} \mathrm{C}$ for $5 \mathrm{hrs}$ to reduce the moisture content to between 5 and $6 \%$. The testa of the dried kernels were removed manually, packaged and stored.

\section{Preparation of defatted cashew kernel powder}

The defatted cashew nut powder was produced as described by Sze-Tao and Sathe [11]; cashew kernels were ground using a pestle and mortar. The flakes were then extracted with n-hexane two times using a flake to solvent ratio of $1: 10(\mathrm{w} / \mathrm{v})$ with continuous magnetic stirring (1-kamag, Drehzahl, Germany) for 1 hour. The defatted flakes were then spread on a stainless tray and put under a fume cupboard for $6 \mathrm{hr}$ to dry and to remove traces of solvent. The flakes was then ground to obtain $150 \mu \mathrm{m}$ flour, packed in plastic tubes and stored at $-10^{\circ} \mathrm{C}$.

\section{Proximate analysis}

The proximate compositions of the cashew nut and cashew meal samples were determined using the method of AOAC [12].

\section{Extraction of cashew nut proteins}

\section{M ethod 1: Alkaline extraction-isoelectric precipitation method (IP)}

The method of Wagner et al. [13] was used for the alkaline extraction-isoelectric precipitation production of proteins; the defatted cashew nut flour was extracted at room temperature (about $20^{\circ} \mathrm{C}$ ) by using two different cashew nut powder to water ratios of 1:5, and 1:10. The distilled water used was also adjusted to two different $\mathrm{pH}$ values of 7.0 and 9.0, using $0.1 \mathrm{~N} \mathrm{NaOH}$, as used Wagner et al. [13] for the production of soy protein fractions. The suspension was stirred using a magnetic stirrer for 1 hour, and then cold-centrifuged using $1 \mathrm{~S}-\mathrm{R}$, Heraeus Multifuge, Germany at $1000 \mathrm{x}$ $\mathrm{G}$ for $30 \mathrm{~min}$, at $4^{0} \mathrm{C}$. The insoluble cashew protein cake was re-slurried with $\mathrm{pH}$ adjusted distilled water as above, and cold-centrifuged again. The supernatants were mixed together, divided into two and adjusted to two different $\mathrm{pH}$ values of 3.5 and 4.5 by addition of $0.1 \mathrm{~N} \mathrm{HCl}$, and allowed to stand for $2 \mathrm{hr}$ at $4^{0} \mathrm{C}$, before being centrifuged again for $30 \mathrm{~min}$ at $4^{0} \mathrm{C}$ and $1000 \mathrm{x}$ G. The supernatants were poured off to obtain cashew protein slurry which was at the bottom of the flask. The slurry was 
re-suspended in water of $\mathrm{pH} 3.5$ and 4.5 and the extraction was repeated as above to obtain cashew slurry. The cashew protein slurry was freeze-dried in CHRIST FreezeDrying system (Alpha 2-4, Martins Christ, Germany) for 12 hours. The cashew proteins were then ground in a laboratory mill so as to pass through a mesh screen of standard No 103 and then packaged.

The proteins were stored at $-10^{0} \mathrm{C}$. All reported values are the average of triplicate experiments.

\section{M ethod 11: A lkaline extraction-methanol precipitation method (M P)}

The method of Hanson [14] was used for the alkaline extraction-methanol precipitation of cashew protein; the defatted cashew nut flour was extracted at room temperature (about $20^{\circ} \mathrm{C}$ ) by using two different cashew nut powders to water ratios of 1:5, and 1:10. The distilled water used was also adjusted to $\mathrm{pH}$ of 7.0 and 9.0, using $0.1 \mathrm{~N} \mathrm{NaOH}$. The suspension was stirred using a magnetic stirrer for $1 \mathrm{hr}$. Insoluble material was separated from the filtrate by filtration using Vacuum filter. The insoluble cashew protein cake was re-slurried with $\mathrm{pH}$ adjusted water as above, and filtered again. The filtrates were mixed together, divided into two and mixed with two different methanol concentrations (70 and $80 \%$ ); it was allowed to stand for $2 \mathrm{hrs}$ at $4^{0} \mathrm{C}$, and then cold-centrifuged (using $1 \mathrm{~S}-\mathrm{R}$, Heraeus Multifuge, Germany) at $1000 \mathrm{x}$ $\mathrm{G}$ for $30 \mathrm{~min}$. The supernatant was poured off to obtain cashew protein slurry which was at the bottom of the flask. The slurry was re-suspended with 70 and $80 \%$ methanol before the extraction was repeated as above, to obtain purer cashew protein fractions. The alcohol was removed from the cashew nut protein fractions slurry using a vacuum desolventiser. The cashew nut protein fraction slurry was freeze-dried in a freeze-drier (Alpha 2-4, Martins Christ, Germany,) for $12 \mathrm{hrs}$. The cashew nut protein fractions were then ground in a laboratory mill so as to pass through a mesh screen of standard No. 103 and then packaged.

The protein fractions were stored at $-10^{0} \mathrm{C}$, All reported values are averages of triplicate determinations.

\section{Protein content determination}

The protein content of the cashew meal and sixteen cashew nut protein fractions produced as described above, were carried out using 2-D Quant Kit method [15];

Sample solubilization: $30 \mathrm{mg}$ of each sample was solubilized with $1500 \mu \mathrm{l}$ RLH buffer $(20 \mu \mathrm{l}$ Dithiothreitol $\{\mathrm{DTT}\}+5 \mu \mathrm{l} \mathrm{G}-\mathrm{V}+1 \mathrm{~mL}$ RLA at $\mathrm{pH} 3-10)$. The solution was vortexed, heated in water bath at $35^{\circ} \mathrm{C}$ for $5 \mathrm{~min}$ and incubated at $37^{\circ} \mathrm{C}$ while shaking for $1 \mathrm{hr}$. The solution was then centrifuged at $22^{\circ} \mathrm{C}$ and $18000 \mathrm{rpm}$ for 15 min. Part of the solution $(500 \mu \mathrm{l})$ was then pipette into an Ultra-centrifugal filter and centrifuge at $10000 \mathrm{rpm}$ for $15 \mathrm{~min}$ at $22^{\circ} \mathrm{C}$. The clear solutions of the samples were pipetted into tubes. The filtration process was repeated until the sample solutions were exhausted. The volumes of the clear solutions obtained were then recorded. 
Preparation of colour reagent: 100 parts of colour reagent A were mixed with 1 part of colour reagent B. These colour reagents are part of the kit components and their identities were not disclosed.

Preparation of standard curve: Bovine Serum Albumin (BSA) of concentration of $10,20,30,40$, and $50 \mu 1 / \mathrm{mg}$ were prepared and used as standard.

Analysis: Precipitant $(500 \mu 1)$, was added to both the samples and standard, vortexed and incubated at room temperature (about $20^{\circ} \mathrm{C}$ ) for $15 \mathrm{~min}$. Co-Precipitant was also added, mixed and the mixture was centrifuged at $10000 \times \mathrm{G}$ for $15 \mathrm{~min}$. The supernatants were then centrifuged and the remaining supernatant removed with a micropipette. Copper solution $(100 \mu 1)$ and $400 \mu 1$ distilled water were added to each sample and standard. The solution was then vortexed to dissolve the precipitated protein. Working color reagent $(1 \mathrm{~mL})$ was added, incubated at room temperature for $20 \mathrm{~min}$ and the absorbance was read at $480 \mathrm{~nm}$ within $30 \mathrm{~min}$ of addition of colour, to assay the colour density which is inversely related to the concentration of protein in the sample.

Protein content calculation: This was done based on the standard curve obtained from the standard concentrations as prepared above and each sample curve gave the protein content in microgram per micro litre. This was then calculated back using the solvent volume and the weight of each sample. All reported values are averages of triplicate sample readings.

Statistical analysis: Determinations were made in triplicates; standard errors of the mean (SEM) and analysis of variance (ANOVA) in SPSS 10 were used to analyze the results. Means were separated using Duncan multiple range test. Significance was accepted at 0.05 level of probability.

\section{RESULTS}

\section{Proximate composition of cashew nut and meal}

Results of the proximate analysis of cashew nut (Table 1) showed that cashew nut composed of $21.70 \%$ protein, and $47.20 \%$ fat. Also, the protein content of defatted cashew nut flour increased to $43.20 \%$ (Table 1), while its fat content was reduced to $4.8 \%$. Also, carbohydrate contents of the defatted cashew nut flour increased from $62.70 \%$ to $75.20 \%$, while the moisture content decreased from 1.81 to $0.85 \%$ (Table 1).

Protein yield and content of cashew nut protein fractions produced by alkaline extraction -isoelectric precipitation (IP) method

Table 2 showed the effects of extraction ratio, extraction $\mathrm{pH}$, and precipitation $\mathrm{pH}$ on the protein yield and protein contents of cashew nut protein fractions produced by alkaline extraction-isoelectric precipitation (IP) method. The highest protein yield (98.9\%) was obtained from CNPIP 8 method with an extraction ratio 1:10, an extraction $\mathrm{pH}$ 9.0, and a precipitation $\mathrm{pH}$ 4.5. This was followed by CNPIP 4 method 
with a 1:5 extraction ratio, 9.0 extraction $\mathrm{pH}$, and 4.5 precipitation $\mathrm{pH}$ which gave $90.6 \%$ protein yield. The lowest protein yield $(44.4 \%)$ was obtained from CNPIP 1 with extraction ratio 1:5, extraction $\mathrm{pH} 7.0$, and precipitation $\mathrm{pH} 3.5$. The highest protein content $(99.8 \%)$ was obtained using the CNPIP 8 method, while the lowest protein content (44.4) was obtained using CNPIP 1 method.

Protein yield and content of cashew nut protein fractions produced by alkaline extraction-methanol precipitation (M P) method

Table 3 showed the effects of extraction ratio, extraction $\mathrm{pH}$, and precipitation concentrations on the protein yield and protein contents of cashew nut protein produced by alkaline extraction-methanol precipitation (MP) method. The highest protein yield $(88.2 \%)$ was obtained from CNPMP 4 method with extraction ratio of $1: 10$, extraction $\mathrm{pH} 9.0$, and precipitation with methanol of $70 \%$ concentration. While the least protein yields $(52.1 \%)$ was obtained from CNPMP 7 method with extraction ratio of 1:10, extraction $\mathrm{pH} 7.0$, and methanol concentration $80 \%$. The highest protein content $(89.2 \%)$ was obtained from the same CNPMP 4 method that gave the highest protein yield. Also, the first two highest protein contents $(89.2 \%$, and $85.7 \%$ ) were obtained from CNPMP 3 and 4 with a $70 \%$ precipitation methanol concentration.

\section{DISCUSSION}

Cashew nut contained $21.70 \%$ protein, and $47.20 \%$ fat, values which were within the range of value reported by Amoo [16]. The protein content of the defatted cashew nut flour increased to $43.20 \%$, as, while its fat content was reduced to $4.8 \%$. According to Tranchino et al. [17], solvent extraction (usually hexane) allows near total extraction of the oil (leaving a lipid residue of 1-1.5\%). The proximate composition of cashew nut and the defatted cashew nut flour were comparable to that of the pea nut $(25.3 \%$ protein, and $40.1 \%$ fat) as reported by Nandi [18], and defatted pea nut flour (45\% protein, and $4.2 \%$ fat) as reported by Wagner et al. [13]. This was done to ascertain the suitability of cashew nut for protein concentrate and isolate production, since pea nut has been used for the production of protein isolates [19], and protein concentrates [20]. Also, the carbohydrate contents of the defatted cashew nut flour increased from $62.70 \%$ to $75.20 \%$, while the moisture content decreased from 1.81 to $0.85 \%$. Due to the removal of most oil in the cashew nut, the proximate composition of the cashew nut was significantly different $(\mathrm{p}<0.05)$ from that of cashew meal.

The extraction ratio, extraction $\mathrm{pH}$, and precipitation $\mathrm{pH}$ influenced the protein yield and protein contents of cashew nut protein fractions produced by alkaline extractionisoelectric precipitation (IP) method. The highest protein yield (98.9\%) was obtained from CNPIP 8 method with an extraction ratio of 1:10, extraction $\mathrm{pH} 9.0$, and precipitation $\mathrm{pH}$ of 4.5. This was followed by the CNPIP 4 method with a 1:5 extraction ratio, 9.0 extraction $\mathrm{pH}$ and 4.5 precipitation $\mathrm{pH}$ that gave $90.6 \%$ protein yield. This confirmed the findings of Damodaran [21] that most proteins are highly soluble at alkaline $\mathrm{pH}(7-9)$, and that protein extraction from plant sources is best carried out at this $\mathrm{pH}$ range, and the protein is best recovered from the extract by isoelectric precipitation at $\mathrm{pH} 4.5-4.8$. Also, it was reported that, all the non-protein

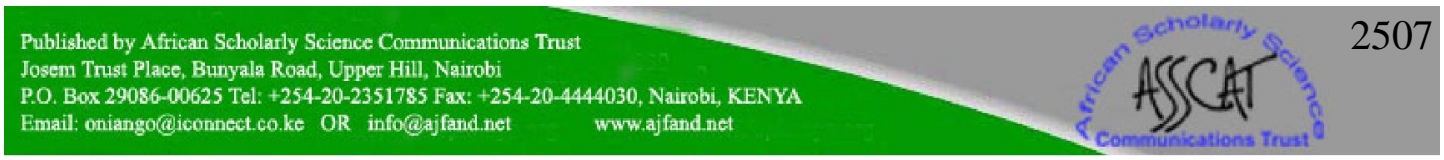


components of sunflower seed may be removed with a protein solubilization operation at alkaline $\mathrm{pH}$, while precipitation of the proteins is achieved when the solution is brought to an acid $\mathrm{pH}$ [17]. The lowest protein yield (44.4\%) was obtained from the CNPIP 1 method, with an extraction ratio 1:5, extraction $\mathrm{pH} 7.0$, and precipitation $\mathrm{pH}$ of 3.5. From these results it could be deduced that, extraction $\mathrm{pH} 9.0$ and precipitation $\mathrm{pH} 4.5$ are the most suitable conditions for the production of cashew nut protein isolates by the IP method as they gave the first and second highest protein contents out of the eight IP methods used. Protein yield is an important factor in the commercial production of vegetable protein concentrates and isolates as it gives an indication of the efficiency of the method used. Protein yield of the protein isolates produced using CNPIP 2, 3, 4, 5, 7, and 8 methods were significantly different ( $p$ < 0.05 ) from each other, while the protein content of the protein isolate produced by CNPIP 1 and CNPIP 6 methods were significantly different from one another, and are significantly different from others at 5\% probability level. Protein content determines whether a product is a protein concentrate or protein isolate. According to the Codex Alimentarius Commission, a product is defined as protein flour, if the protein content is between $50 \%-65 \%$, protein concentrate if it has $65 \%-90 \%$ protein content, and as a protein isolate when it contains protein content of $90 \%$ and above [22]. The highest protein content $(99.8 \%)$ was obtained from the CNPIP 8 method, while the lowest protein content (44.4) was obtained with the CNPIP 1 method. Protein content obtained from the eight IP methods was significantly different $(\mathrm{P}<0.05)$ from each other. However, according to CODEX STAN [22] out of all IP methods, cashew nut protein isolate was produced only from the CNPIP 8 method, which gave $99.8 \%$ protein content; this is similar to what was obtained for pea nut protein isolate [23]. However, cashew nut protein concentrates of protein content 68,78 , and $67 \%$ were produced by the CNPIP 3, 4, and 7 methods, respectively.

The extraction ratio, extraction $\mathrm{pH}$, and methanol precipitation influenced the protein yield and protein contents of cashew nut produced by alkaline extraction-methanol precipitation (MP) method. According to Damodaran [21], extraction of protein with relatively polar organic solvents such as ethanol and methanol, may be necessary to reduce off-flavour in the final product. The highest protein yield $(88.2 \%)$ was obtained with the CNPMP 4 method with an extraction ratio of 1:10, an extraction $\mathrm{pH}$ 9.0, and a precipitation methanol concentration of $70 \%$. The least protein yield (52.1\%) was obtained with the CNPMP 7 method with an extraction ratio of 1:10, extraction $\mathrm{pH} 7.0$, and a methanol concentration $80 \%$. The highest protein content $(89.2 \%)$ was obtained from the same CNPMP 4 method that gave the highest protein yield. This confirmed the results from the IP methods that extraction ratio and $\mathrm{pH}$ of 1:10 and 9.0, respectively, were the most suitable conditions for the extraction of protein from cashew nut. It could then be deduced that, since the first two highest protein contents (89.2\% and 85.7\%) were obtained from CNPMP 3 method and 4 with a $70 \%$ methanol concentration, the $70 \%$ methanol concentration is the most suitable for the production of cashew nut protein. This agrees with the results obtained by Adebowale [24] on the production of Mucuna bean protein isolates precipitated using ethanol. It was also reported by Moure et al [7] that, the commercial production of soya protein concentrate was achieved by the use of $85 \%$ methanol. It was reported 
by Sodini and Canella [25] that high total protein yields and content were obtained with the precipitation of protein using methanol. Protein yield of $72 \%$ was obtained for protein concentrate production. The protein contents with the CNPMP 2 and 7 methods were not significantly different from one another at 5\% probability level. According to CODEX STAN [22], the MP method was not suitable for the production of cashew nut protein isolates, as the protein contents obtained from this method were less than 90\%. However, all MP methods except CNPMP 6 were suitable for the production of cashew nut protein concentrates, since their protein content are within the $65 \%$ and $90 \%$ acceptable range. This could be due to differences in properties of the solvents and the different processing procedures used.

\section{CONCLUSIONS}

The protein content of cashew nut meal $(43.2 \%)$ and pea nut meal $(45 \%)$ are close to each other, and this established the suitability of cashew nut for the production of protein concentrate and isolate. From the methods used, CNPIP 8 method is the only suitable method for the production of cashew nut protein isolates. Also, from the IP methods used, CNPIP 3, 4, and 7 methods were suitable for the production of cashew nut protein concentrates.

Cashew nut protein isolate of $99.8 \%$ protein content and $98.9 \%$ protein yield was produced using CNPIP 8 method using a 1:10 extraction ratio, 9.0 extraction $\mathrm{pH}$ and isoelectric precipitation at $\mathrm{pH} 4.5$.

Work on the functional and nutritional characterization of the cashew protein concentrates and isolate is on-going.

\section{RECOMMENDATIONS}

The IP method at an extraction ratio of $1: 10$, extraction $\mathrm{pH}$ of 9.0 and a precipitation $\mathrm{pH}$ of 4.5 is recommended for the production of protein isolate from cashew nut, while protein concentrate could be produced using the same method at an extraction ratio of 1:5, extraction $\mathrm{pH}$ of 9.0 and a precipitation $\mathrm{pH}$ of 4.5. However, the MP method is suitable only for the production of protein concentrate from cashew nut at an extraction ratio of 1:10, an extraction $\mathrm{pH} ; 9.0$ and a methanol concentration of $70 \%$.

In the future, enzymes could be used to hydrolyse the extracted proteins to produce cashew nut protein hydrolysate. 


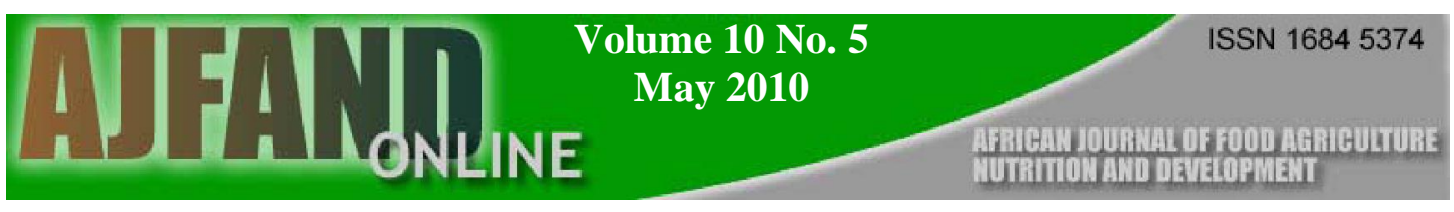

Table 1:Proximate Composition of Cashew Nut and M eal (dry weight basis)

\begin{tabular}{|lcc|}
\hline Composition & Cashew Nut & Cashew M eal \\
\hline Moisture content (\%) & $1.81 \pm 0.01$ & $0.85 \pm 0.04$ \\
Fat content $(\%)$ & $48.38 \pm 0.05$ & $4.80 \pm 0.05$ \\
Protein content $(\%)$ & $20.56 \pm 0.06$ & $43.20 \pm 0.04$ \\
& & $3.00 \pm 0.04$ \\
Ash content $(\%)$ & $3.40 \pm 0.06$ & $75.20 \pm 0.06$ \\
Carbohydrates $(\%)$ & $62.70 \pm 0.06$ & \\
\hline
\end{tabular}


Table 2: Protein yield and content of cashew nut protein fractions produced by Alkaline Extraction - I soelectric Precipitation (I P) M ethod

\begin{tabular}{|c|c|c|c|c|c|}
\hline & Ext. & Ext. & Ppt & Protein & Protein \\
\hline & Ratio & $\mathrm{pH}$ & $\mathrm{pH}$ & Y ield (\%) & Content (\%) \\
\hline CNPIP 1 & $1: 5$ & 7.0 & 3.5 & $57.83 \pm 2.06^{\mathrm{f}}$ & $44.40 \pm 0.10^{h}$ \\
\hline CNPIP 2 & $1: 5$ & 7.0 & 4.5 & $60.60 \pm 0.30^{\mathrm{e}}$ & $63.06 \pm 0.95^{\mathrm{e}}$ \\
\hline CNPIP 3 & $1: 5$ & 9.0 & 3.5 & $69.30 \pm 0.30^{\mathrm{d}}$ & $68.10 \pm 0.20^{\mathrm{c}}$ \\
\hline CNPIP 4 & $1: 5$ & 9.0 & 4.5 & $79.50 \pm 0.50^{c}$ & $78.16 \pm 0.35^{\mathrm{b}}$ \\
\hline CNPIP 5 & $1: 10$ & 7.0 & 3.5 & $48.20 \pm 0.35^{\mathrm{g}}$ & $50.80 \pm 0.30^{\mathrm{g}}$ \\
\hline CNPIP 6 & $1: 10$ & 7.0 & 4.5 & $59.10 \pm 0.10^{\mathrm{f}}$ & $61.43 \pm 0.25^{\mathrm{f}}$ \\
\hline CNPIP 7 & $1: 10$ & 9.0 & 3.5 & $90.60 \pm 0.10^{b}$ & $66.60 \pm 0.40^{\mathrm{d}}$ \\
\hline CNPIP 8 & $1: 10$ & 9.0 & 4.5 & $98.90 \pm 0.00^{\mathrm{a}}$ & $99.80 \pm 0.10^{\mathrm{a}}$ \\
\hline
\end{tabular}

NOTES: a, b, c, d, e, f, g, h means followed by the same alphabets on the same column are not significantly different at $\mathrm{p}<0.05$.

CNPIP: Cashew nut protein-isoelectric point precipitated.

EXT: Extraction

PpT: Precipitation. 
Table 3:Protein yield and content of cashew nut proteins fractions produced by alkaline extraction-methanol precipitation (M P) methods

\begin{tabular}{|c|c|c|c|c|c|}
\hline & Ext. & Ext. & $M$ eth. & Protein & Protein \\
\hline & Ratio & $\mathrm{pH}$ & Conc. $(\%)$ & Y ield (\%) & Content (\%). \\
\hline CNPMP 1 & $1: 5$ & 7.0 & 70.0 & $55.33 \pm 0.15^{\mathrm{f}}$ & $70.30 \pm 0.20^{\mathrm{de}}$ \\
\hline CNPMP 2 & $1: 5$ & 9.0 & 70.0 & $57.90 \pm 0.20^{\mathrm{e}}$ & $72.30 \pm 0.10^{\mathrm{cd}}$ \\
\hline CNPMP 3 & $1: 10$ & 7.0 & 70.0 & $59.33 \pm 1.16^{\mathrm{d}}$ & $85.70 \pm 0.10^{b}$ \\
\hline CNPMP 4 & $1: 10$ & 9.0 & 70.0 & $88.20 \pm 0.10^{\mathrm{a}}$ & $89.20 \pm 0.10^{\mathrm{a}}$ \\
\hline CNPMP 5 & $1: 5$ & 7.0 & 80.0 & $58.53 \pm 0.06^{\mathrm{e}}$ & $68.20 \pm 0.20^{\mathrm{e}}$ \\
\hline CNPMP 6 & $1: 5$ & 9.0 & 80.0 & $61.70 \pm 0.10^{c}$ & $64.00 \pm 0.10^{\mathrm{f}}$ \\
\hline CNPMP 7 & $1: 10$ & 7.0 & 80.0 & $52.10 \pm 0.17^{\mathrm{g}}$ & $72.40 \pm 0.10^{\mathrm{cd}}$ \\
\hline CNPMP 8 & $1: 10$ & 9.0 & 80.0 & $63.10 \pm 0.17^{\mathrm{b}}$ & $74.56 \pm 3.86^{\mathrm{cd}}$ \\
\hline
\end{tabular}

NOTES: ${ }^{a}, b, c, d, e, f, g$, means followed by the same alphabetic on the column are not significantly different at $\mathrm{p}<0.05$.

CNPMP: Cashew nut protein-methanol precipitated.

EXT: Extraction

Meth conc: Methanol concentration 


\section{REFERENCES}

1. B ehrens R Cashew as an Agroforestry Crop; Prospects and Potentials; Margraf Verlag: Weikersheim, Germany, 1996: 83.

2. J oseph KT Cashew nut: A valuable nutritive food product. Indian Cashew Journal (India) 1975; 10 (2): 5-6.

3. Fetuga $B L, B$ abatunde GM, Ekpenyong TB and VA Oyenuga The feeding stuff potential of cashew nut scraps kernel meal. Proceedings of the Conference of Animal feed of Tropical and sub-tropical origin. Tropical products Institute (London), 1975; 201-207.

4. K apur NS, Pirasad $M$ and PM M athur Processing and storage of cashew nuts and kernels. Indian Food Packer, 1975; 6 (8): 27-30.

5. Ogunwolu SO and TO Akinwale Production and Nutritional composition of non-convectional chocolate products in the tropics. J. Nutr. Fd. Sci. 2003; 33 (3): $120-124$.

6. Penny C Proteins-The essential ingredients. J. Fd. Ingr. Proc. Inter; . 1999: 1419.

7. Moure A, Sineiro J, Dominguez H and J S Parajo Functionality of oilseed protein products: A review. Nutr Res. 2003; 11: 1147 - 1154.

8. Cherry J C, McWatters KH and MR Holmes Effects of moist heat on solubility and structural components of pea nut protein. J. Food. Sci. 1975; 40 1199-1205.

9. Mcwatters $\mathrm{KH}$ and JP Cherry Emulsification: Vegetable proteins functionality in foods. Am. Chem. 1981; 98 (2): 558-68.

10. Falade $\mathrm{KO}, \mathrm{Chime} \mathrm{JJ} \mathrm{and} \mathrm{SO} \mathrm{Ogunwolu} \mathrm{Water} \mathrm{sorption} \mathrm{isotherms} \mathrm{and} \mathrm{heat}$ of sorption of cashew nuts pretreated by different methods, J. Fd. Agric. \& Environ. 2004; 2 (2): 83-7.

11. Sze-Tao K W C and SK Sathe Functional properties and in-vitro digestibility of Almond (Prunus dulcis L) protein isolate. Food chem., 2004; 69: 153- 160.

12. AOAC. Official Methods of Analysis, $16^{\text {th }}$ ed., Association of Official Analytical Chemists, Washington DC. 1990.

13. Wagner JR, Sorgentini DA and MC A non Relationship between solubility and surface hydrophobicity as an indicator of modification during preparation processes of commercial and laboratory prepared Soy-protein Isolates. J. Agric. Food Chem. 2000; 48: 3159-3165. 
14. Hanson LP Vegetable protein processing. Food Technology Review 1974; 16: 89-106.

15. Amercham Biosciences 2-D Quant kit method for protein. A handbook on protein analysis. Amercham, Buckinghamshire, England. 2003.

16. A moo IA Proximate composition, minerals, and physico-chemical properties of cashew nut and oil. J. Fd. Sci. and Tech. Mysore. 2005; 42 (5): 445-446.

17. Tranchino $L$, Constantino $R$ and $G$ Sodini Food grade oil seed protein processing: Sunflower and Rapeseed, Qual, Plant foods for Human Nutrition $1983 ; 32: 305-334$.

18. Nandi BK Cashew nut nutritional aspects; Integrated production practices of cashew in Asia. FAO Corporate Document Repository FAO, Rome. 1990.

19. Sumner AK, Nielsen MA and CG Y oungs Production and evaluation of pea isolate. Presented at the $40^{\text {th }}$ annual meeting, Institute of Food Technology, New Orleans, LA. 1980.

20. M onteiro PV and V Prakash Functional properties of homogeneous protein fractions from peanut (Arachi hypogaea L.). J. Agric. Food Chem. 1994; 42 (2): 274-278.

21. Damodaran S Food proteins: An overview. In S. Damodaran and Paraf. A. (Eds.), Food proteins and their applications. New York: Marcel Dekker, 1997: $1-21$.

22. Codex Alimentarius Commission. Codex standards for vegetable proteins and general guidelines for the utilization of vegetable protein products. Food and Agriculture Organization of the United Nations. World Health Organization Rome. First edition, supplement 1 to Codex Alimentarius. CODEX STAN 175. 1989.

23. Manak LJ, Lawhon JT and EW Lusa Functioning potential of Soy, Cottonseed, and Peanut Isolates produced by Industrial membrane systems. J. Food. Sc. 1980; 45 ( 2): 236-238, 245.

24. Adebowale YA Isolation and fractionation of protein from mucuna bean. In 2005 IFT annual meeting book of abstracts, New Orleans July 15-20, 2005.

25. Sodini G and M Canella Extraction of phenols and oligosaccharides from plant tissue. German Patent, 1976: DE 2606961. 